\section{External Hexagon Deformation in Implants Subjected to Internal Torque}

Denildo Magalhães ${ }^{1}$, Marina Melo Naves ${ }^{1}$, Helder Henrique Machado Menezes $^{2}$, César Bataglion ${ }^{3}$, Guilherme Carminati Magalhães ${ }^{4}$, Paulo César Freitas Santos Filho ${ }^{5}$

\author{
'Department of Periodontology, \\ Dental School, UFU - Federal \\ University of Uberlândia, \\ Uberlândia, MG, Brazil \\ ${ }^{2}$ Department of Implantology, \\ HD Post-graduation Dental \\ School, Uberlândia, MG, Brazil \\ ${ }^{3}$ Department of Prosthodontics, \\ Ribeirão Preto Dental School, \\ USP - São Paulo University. \\ Ribeirão Preto, SP, Brazil \\ ${ }^{4}$ Department of Post Graduation, \\ Dental School, UFU - Federal \\ University of Uberlândia, \\ Uberlândia, MG, Brazil \\ ${ }^{5}$ Department of Dental Materials, \\ Dental School, UFU - Federal \\ University of Uberlândia, \\ Uberlândia, MG, Brazil
}

\begin{abstract}
Correspondence: Prof. Dr. Denildo Magalhães, Avenida Pará, 1720 - Campus Umuarama - Bloco 4L - 38405-902 Uberlândia, MG, Brasil. Tel.: +55-34-3218-2255 | +55-34-99121-6665. e-mail: denildomagalhaes@gmail.com
\end{abstract}

Key Words: dental implants, abutment connection, torque.

\section{Introduction}

In the last few years osseointegrated implants have provided important contributions to dental implant therapy and improvements in the functional and esthetic quality of edentulous rehabilitation. Considering that successful establishment and maintenance of osseointegration are affected by biomechanics (1), numerous studies have been conducted on the engineering properties of dental implants, e.g., the types of implant-abutment connections (2-4).

The external hexagon (EH) implant system was initially designed to transmit the rotational torque, which was applied on the external surface of the EH (external torque), for dental implant placement (5). Although these implants have been the most frequently performed, fatigue or overload failures such as deformation of the hexagon may occur during surgical placement of the implants, due to their different manufacturing tolerances. Higher insertion torque values reduce the risk of implant micromovements at the bone-implant interface, thereby obtaining higher rates of success of immediately loaded implants $(6,7)$. On the other hand, implants can undergo morphological changes during torsion when inserted into bone (8). These changes, associated with the masticatory load, may affect the rotational freedom between implant and abutment and, hence, affect the implant/abutment stability (9-11).
Therefore, an accurate adaptation between the $\mathrm{EH}$ and the prosthetic component results in good biomechanical and aesthetic conditions for rehabilitation by osseointegrated implants (9).

Application of rotational force to the internal surface of the EH (internal torque) has been suggested to reduce the possibility of geometrical deformation of the EH (14), due to the greater resistance of the internal surface as compared to the external surface (9). These systems use the internal contact with the implant walls instead of mounting devices to apply the force, which simplifies the procedure and diminishes the cost of materials. However, system mechanisms will always reach limited resistance, and excessive torque may cause damage to the upper part of the implant, and to the connection to which prosthetic components are attached $(13,14)$. In view of the possibility that external torque may affect the $\mathrm{EH}$ geometrical integrity, one may hypothesize that the application of internal forces may also cause changes in the EH external surface. The aim of this study was to evaluate, in vitro, the levels of deformation of EH following the application of internal torque.

\section{Material and Methods}

Forty implants $(13.0 \mathrm{~mm}$ long $\times 3.75 \mathrm{~mm}$ wide, $4.1 \mathrm{~mm}$ platform) with $\mathrm{EH}$ and internal torque from two commercial 
brands - Titamax Ti implants (N group, 20 implants; Neodent, Curitiba, PR, Brazil) and Tryon implants (S group, 20 implants; SIN, São Paulo, SP, Brazil) were used (Figs. 1A and 1B). The implants were positioned in a stainless steel matrix (30 mm x $125 \mathrm{~mm}$ ), with four regularly, linearly distributed $3.0 \mathrm{~cm}$ holes on the bottom and fixed in acrylic resin (VIPI Class, Pirassununga, SP, Brazil) in order to maintain a static positioning. These holes enabled stabilization of the implant in the matrix from outside using healing abutments $(2 \mathrm{~mm}$ high), and also to simulate the final position of the implant in relation to the bone, i.e., the prosthetic fit at bone level and exposure of the implant.

Following the attachment of the implant to the stainless steel matrix, the matrix was lubricated with liquid paraffin (Farmax, Juiz de Fora, MG, Brazil), filled with chemically activated acrylic resin and heat-polymerized at 4.0 bar pressure for $10 \mathrm{~min}$ (Auto pressure polymerizer; Mestra Polyplus, Belo Horizonte, MG, Brazil). The models were then numbered from 1 to 4 , and the implants identified with a number corresponding to the torque values, which were established based on the specifications given by the manufacturer of each group ( $\mathrm{N}$ - Neodent / S - SIN), which were divided into 5 subgroups. In the $\mathrm{N}$ group, Model \#1 (No) did not receive torque and was used as control, Model \#2 (N32) was subjected to a $32 \mathrm{Ncm}$ torque, Model \#3 (N45) to $45 \mathrm{Ncm}$ torque, Model \#4 (N60) to $60 \mathrm{Ncm}$ torque and Model \#5 (N80) to $80 \mathrm{Ncm}$ torque. In the $\mathrm{S}$ group, Model \#1 (S0) did not receive torque and was used as control, Model \#2 (S30) was subjected to a $30 \mathrm{Ncm}$ torque, Model \#3 (S40) to $40 \mathrm{Ncm}$ torque, Model \#4 (S60) to $60 \mathrm{Ncm}$ of torque and Model \#5 $(\mathrm{S} \infty)$ to infinite torque (>60 Ncm). Specific ratchet torque wrenches were used for each group, following the specifications set by the manufacturers (Figs. $2 \mathrm{~A}$ and $2 \mathrm{~B})$, and one torque wrench was used for each implant model to avoid deformation of the wrench. The application of torques was performed by a single operator, who simulated the surgical procedure of dental implant, as follows: first the models were statically attached to a lathe, the operator positioned the internal wrench in the EH and then performed one slow, continuous, rotational movement,
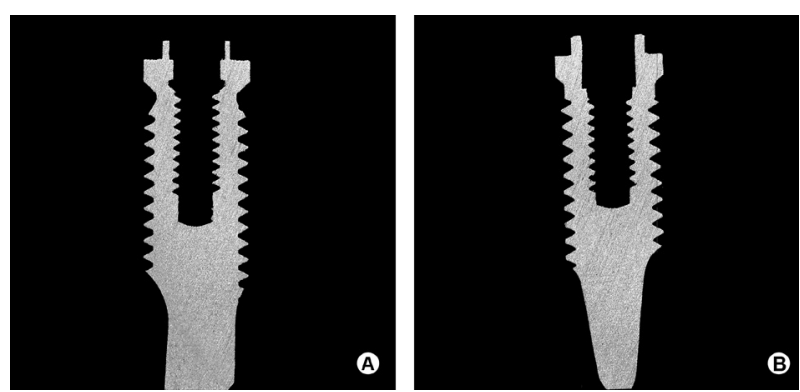

Figure 1. External and internal view of the $\mathrm{N}$ implant (A) and S implant (B). until the desired torque was achieved. This procedure was repeated with all implant models (Figs. $3 \mathrm{~A}$ and $3 \mathrm{~B}$ ).

The implants were photographed by a digital camera attached to a copy stand, which was positioned perpendicular to the hexagon and the platform before and after torque application. Hexagon deformation was calculated by the Image Tools 3.0 software (UTHSCSA, San Antonio, TX, USA), which was developed for image processing and analysis in terms of distance, angle, perimeter and area. Also, spatial calibration of the software enabled capturing the images in millimeters. The following EH measures were performed - internal dimensions (ID) $(\mathrm{mm})$ : distance between opposite vertices of the hexagon, measured on its internal face, with A2/B2/C2 defined as the distance between the two central points of opposite vertices, $\mathrm{A} 1 / \mathrm{B} 1 / \mathrm{C} 1$ defined as the distance between the points located at $0.25 \mathrm{~mm}$ to the left of each opposite vertix, $A 3 / B 3 / C 3$ defined as the distance between the points located at $0.25 \mathrm{~mm}$ to the right of each opposite vertix; internal area (IA) $\left(\mathrm{mm}^{2}\right)$ defined as the area of the EH internal face; and external area (EA) $\left(\mathrm{mm}^{2}\right)$ defined as the area of the EH external face (Fig. 4). Mean values of ID, IA and EA obtained before and after torque application and the percentage of deformation were calculated. The Scott-Knott test was used for multiple comparisons, using a univariate cluster analysis (15).

\section{Results}

Means and standard deviations of ID deformation (\%) by

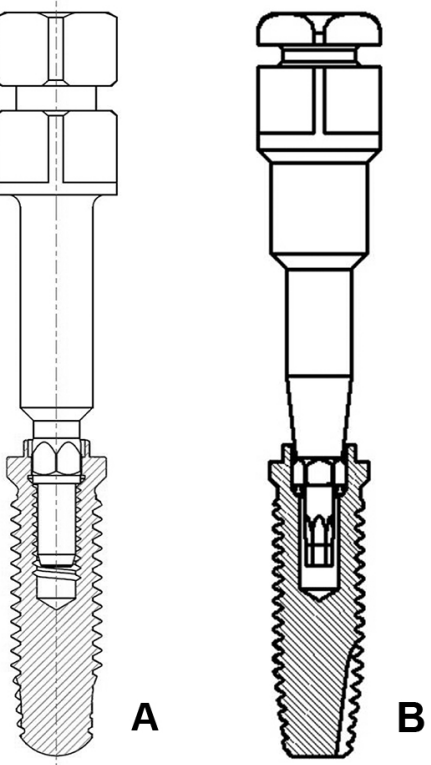

Figure 2. Implants of $\mathrm{N}$ group $(\mathrm{A})$ and $\mathrm{S}$ group (B) and respective ratchet torque wrenches used for each group, following the specifications set by the manufactures. 
group are presented in Figures $5 \mathrm{~A}$ and $5 \mathrm{~B}$. Increase in all $\mathrm{EH}$ measures was observed, which was related to the increase of torque. The measure with the greatest deformation percentage was $\mathrm{A} 3 / \mathrm{B} 3 / \mathrm{C} 3$.

The $\mathrm{N} 60$ and $\mathrm{N} 80$ implant models in the $\mathrm{N}$ group (Table 1) and the $S 60$ and $S_{\infty}$ in the $S$ group (Table 2) showed statistically significant ID deformation (\%) for all measures. The IA and EA values are shown in Figures $6 \mathrm{~A}$ and $6 B$. Similar initial and final mean values of IA and EA were obtained for NO (IA: $3.70 \mathrm{~mm}^{2}$; EA: $\left.6.40 \mathrm{~mm}^{2}\right)$ and SO (IA: $3.70 \mathrm{~mm}^{2}$; EA: $6.48 \mathrm{~mm}^{2}$ ). The other implants showed increased IA and EA values with the increase of torque, except for the EA of N32, N45 and S30 (Fig. 6A). In the N group, changes in the IA were equal or less than $0.09 \mathrm{~mm}^{2}$ for N32, N45 and N60, and $0.13 \mathrm{~mm}^{2}$ for N80. Changes in the EA were found in lesser extent than in $I A$, observed in $\mathrm{N} 45\left(0.01 \mathrm{~mm}^{2}\right)$ and $\mathrm{N} 60\left(0.03 \mathrm{~mm}^{2}\right)$ only. In the $\mathrm{S}$ group, except for the S30 model, significant increases in the IA and EA following torque application were observed for all implant models (Fig. 6B). The IA deformation values were $0.07 \mathrm{~mm}^{2}$ (S30), $0.09 \mathrm{~mm}^{2}$ (S45), $0.12 \mathrm{~mm}^{2}$ (S60) and 0.14 $\mathrm{mm}^{2}(\mathrm{~S} \infty)$, and the EA deformation values were $0.03 \mathrm{~mm}^{2}$ $(\mathrm{S} 45), 0.11 \mathrm{~mm}^{2}(\mathrm{~S} 60)$ and $0.138 \mathrm{~mm}^{2}(\mathrm{~S} \infty)$.

\section{Discussion}

The EH implant interface transmits the rotational force for insertion of the implant into the bone by applying an external or internal torque, whereas the EH/prosthetic abutment interface provides physical stability to the abutment on inserted implant. Both junctions require a dimensional freedom for an accurate, passive fit of the abutment to implant connection $(4,11)$.

Deformations in the geometry of EH caused by external torque (16) have led to the use of internal torque, since the internal area of the implant exhibits greater resistance as compared to the external area. Therefore, in order to identify possible changes in the internal area of the implant

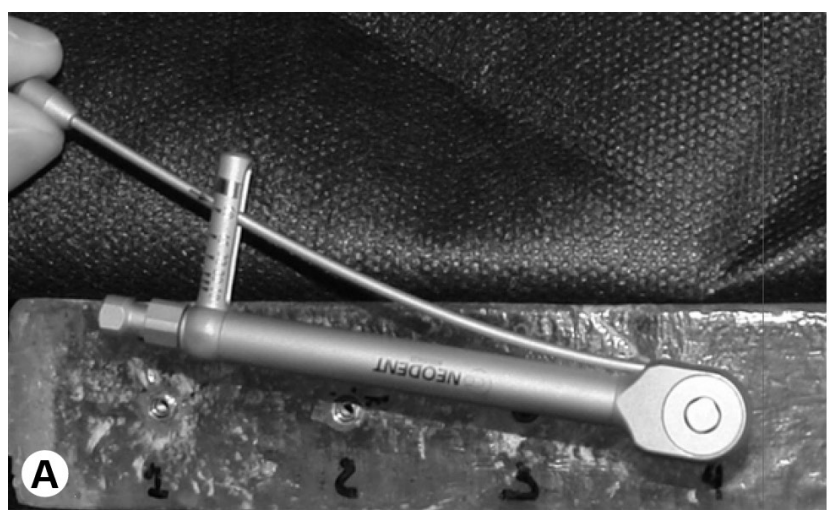

and to exclude interfering variables, the static positioning of the implants into the acrylic model was chosen for the application of torque in this study. This was highlighted by the comparisons between the implant models and the controls ( $\mathrm{NO}$ and $\mathrm{SO}$ ), which showed similar initial and final measures and, hence, no EH deformation, as depicted in Figure 5 and Tables 1 and 2. Although the acrylic resin does not simulate bone tissue, it allowed excluding the effect of macrogeometry on susceptible movements of insertion torque.

Many factors may affect the quality of implant insertion, including bone density. When high values of torque are applied during EH implant surgical placement, the rotational freedom of the implant abutment can be increased due to changes in the internal angle or area of the EH. Any deformity on the external hexagon can derail prosthetic rehabilitation, especially in single crowns. The ID

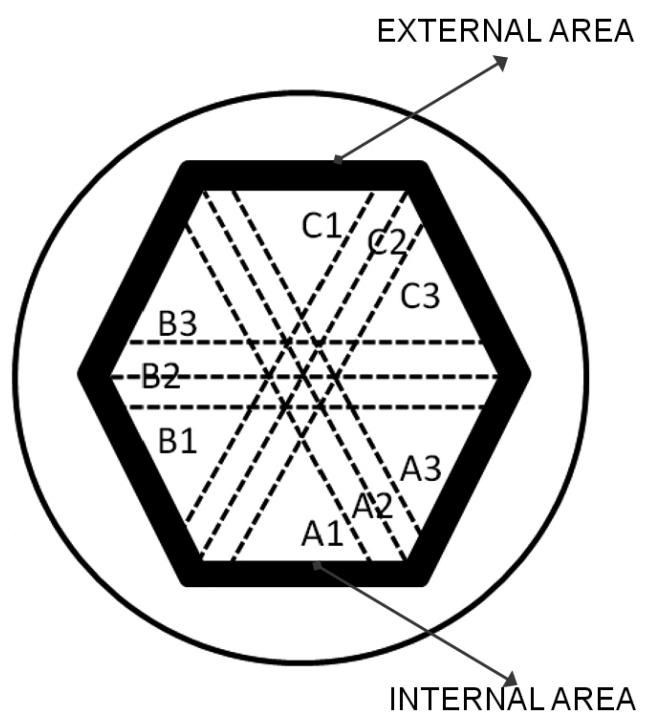

Figure 4. Representation of internal dimension measures, internal and external area of $\mathrm{EH}$.

Figure 3. N group model (A) and S group model (B), used for torque application. 
measures (Fig. 4) quantified the geometry of internal angles in relation to their equivalent opposites before and after the torque was applied. In both groups, the application of torques yielded changes in the evaluated measures (Tables 1 and 2). These changes were not statistically different in N32 and S30, indicating the capacity of these models to resist the torque applied by the operator. For N45 and S40 models, some measures (A2, B1, B3, C2 for $\mathrm{N} 45$ and $\mathrm{A} 1, \mathrm{~B} 1$, $B 2, B 3, C 1, C 3$ for $\mathrm{S} 40$ ) showed significant deformation, suggesting that these models could also resist the torque applied, despite occurring some changes in the angle values. The other models (N60, N80, S60, So) showed statistically significant changes for all measures, indicating an increased rotational freedom of the implant abutment. Figure 6 shows a progressive increase of all measures in both groups, illustrating a tendency for abutment displacement toward the rotational direction, i.e. the $\mathrm{A} 3, \mathrm{~B} 3$ and $\mathrm{C} 3$ values were greater than the $A 2, B 2$ and $C 2$ values, which were greater than the $\mathrm{A} 1, \mathrm{~B} 1$ and $\mathrm{C} 1$ values, resulting in greater differences in the $\mathrm{N}$ group compared with the $\mathrm{S}$ group.

These changes could be identified by the determination of IA measurements, as it was observed increase in the internal area with the increase of the torque values (Fig. 6). It is noteworthy that the N60, N80, S40, S60 and So dimensions were near or greater than $0.1 \mathrm{~mm}^{2}$, and thus capable to increase the rotational freedom of the implant. In addition, the standard deviation values were not high in comparison with the means, indicating that the number of samples used in this study represents the behavior of EH in response to the torque applied. Therefore, considering that changes in both ID and IA occur simultaneously, it is important to consider the impact of such changes, especially in areas of higher bone density, on a greater rotational freedom of implant/abutment interface.

Passive fit between the screw-retained implant prosthesis and $\mathrm{EH}$ is fundamental for the biomechanical stability of the osseointegrated implant, which is negatively affected by changes on the external surface. In this study, although the application of torque caused changes in the ID and IA, most of the implant models showed minimal (N60) or no changes (N32, N45, S30) in the EA (Fig. 6). However, the level of changes observed in the EA of both $\mathrm{N} 80$ and $\mathrm{S} 40,0.59 \%\left(0.038 \mathrm{~mm}^{2}\right)$ and $0.49 \%\left(0.032 \mathrm{~mm}^{2}\right)$ respectively, may affect the correct fit of the prosthesis to the implant. Studies indicate a direct correlation between implant-abutment rotational misfit and screw loosening (10,16-19).

The greatest changes were observed in the S60 (1.69\%, $\left.0.110 \mathrm{~mm}^{2}\right)$ and $\mathrm{S} \infty$ models $\left(2.12 \%, 0.138 \mathrm{~mm}^{2}\right)$, exceeding the $0.1 \mathrm{~mm}^{2}$ value, and hence hindering the $\mathrm{EH} /$ prosthetic abutment junction (7). The higher values of hexagon deformation for $S$ group may be related to the morphology of the inner portion of the implant, where the connection key adapts. There is an internal stop for $\mathrm{N}$ implants that

Table 1. Results of multiple comparisons of internal dimension deformations ( $\mathrm{mm}$ ) at the measuring points (A1, A2, A3, B1, B2, B3, C1, C2 and C3) in response to different levels of torque in the $\mathrm{N}$ group

\begin{tabular}{cccccccccc}
\hline & $\mathrm{A} 1$ & $\mathrm{~A} 2$ & $\mathrm{~A} 3$ & $\mathrm{~B} 1$ & $\mathrm{~B} 2$ & $\mathrm{~B} 3$ & $\mathrm{C} 1$ & $\mathrm{C} 2$ & $\mathrm{C} 3$ \\
\hline $\mathrm{N} 0$ & $0.000^{\mathrm{a}}$ & $0.000^{\mathrm{a}}$ & $0.000^{\mathrm{a}}$ & $0.000^{\mathrm{a}}$ & $0.000^{\mathrm{a}}$ & $0.000^{\mathrm{a}}$ & $0.000^{\mathrm{a}}$ & $0.000^{\mathrm{a}}$ & $0.000^{\mathrm{a}}$ \\
$\mathrm{N} 32$ & $0.008^{\mathrm{a}}$ & $0.008^{\mathrm{a}}$ & $0.023^{\mathrm{a}}$ & $0.009^{\mathrm{a}}$ & $0.008^{\mathrm{a}}$ & $0.023^{\mathrm{a}}$ & $0.007^{\mathrm{a}}$ & $0.010^{\mathrm{a}}$ & $0.027^{\mathrm{a}}$ \\
$\mathrm{N} 45$ & $0.010^{\mathrm{a}}$ & $0.018^{\mathrm{b}}$ & $0.034^{\mathrm{a}}$ & $0.014^{\mathrm{b}}$ & $0.019^{\mathrm{a}}$ & $0.035^{\mathrm{b}}$ & $0.012^{\mathrm{a}}$ & $0.019^{\mathrm{b}}$ & $0.033^{\mathrm{a}}$ \\
$\mathrm{N} 60$ & $0.019^{\mathrm{b}}$ & $0.031^{\mathrm{c}}$ & $0.040^{\mathrm{b}}$ & $0.022^{\mathrm{c}}$ & $0.030^{\mathrm{b}}$ & $0.040^{\mathrm{c}}$ & $0.022^{\mathrm{b}}$ & $0.026^{\mathrm{b}}$ & $0.038^{\mathrm{c}}$ \\
$\mathrm{N} 80$ & $0.024^{\mathrm{b}}$ & $0.040^{\mathrm{d}}$ & $0.045^{\mathrm{b}}$ & $0.027^{\mathrm{c}}$ & $0.036^{\mathrm{b}}$ & $0.044^{\mathrm{d}}$ & $0.027^{\mathrm{b}}$ & $0.036^{\mathrm{c}}$ & $0.044^{\mathrm{c}}$ \\
\hline
\end{tabular}

Same letters between lines indicate lack of statistical difference; Scott-Knott test for multiple comparisons of the means; significance level of 0.05 .

Table 2. Results of multiple comparisons of internal dimension deformations ( $\mathrm{mm})$ at the measuring points (A1, A2, A3, B1, B2, B3, C1, C2 and C3) in response to different levels of torque in the $\mathrm{S}$ group

\begin{tabular}{cccccccccc}
\hline & $\mathrm{A} 1$ & $\mathrm{~A} 2$ & $\mathrm{~A} 3$ & $\mathrm{~B} 1$ & $\mathrm{~B} 2$ & $\mathrm{~B} 3$ & $\mathrm{C} 1$ & $\mathrm{C} 2$ & $\mathrm{C} 3$ \\
\hline $\mathrm{s} 0$ & $0.000^{\mathrm{a}}$ & $0.000^{\mathrm{a}}$ & $0.000^{\mathrm{a}}$ & $0.000^{\mathrm{a}}$ & $0.000^{\mathrm{a}}$ & $0.000^{\mathrm{a}}$ & $0.000^{\mathrm{a}}$ & $0.000^{\mathrm{a}}$ & $0.000^{\mathrm{a}}$ \\
$\mathrm{s} 30$ & $0.009^{\mathrm{a}}$ & $0.012^{\mathrm{a}}$ & $0.032^{\mathrm{a}}$ & $0.012^{\mathrm{a}}$ & $0.012^{\mathrm{a}}$ & $0.030^{\mathrm{a}}$ & $0.011^{\mathrm{a}}$ & $0.015^{\mathrm{a}}$ & $0.032^{\mathrm{a}}$ \\
$\mathrm{s} 40$ & $0.018^{\mathrm{b}}$ & $0.018^{\mathrm{a}}$ & $0.036^{\mathrm{a}}$ & $0.016^{\mathrm{b}}$ & $0.020^{\mathrm{b}}$ & $0.036^{\mathrm{b}}$ & $0.021^{\mathrm{b}}$ & $0.021^{\mathrm{a}}$ & $0.038^{\mathrm{b}}$ \\
$\mathrm{s} 60$ & $0.023^{\mathrm{b}}$ & $0.031^{\mathrm{b}}$ & $0.042^{\mathrm{b}}$ & $0.031^{\mathrm{c}}$ & $0.029^{\mathrm{c}}$ & $0.041^{\mathrm{b}}$ & $0.018^{\mathrm{c}}$ & $0.031^{\mathrm{b}}$ & $0.042^{\mathrm{c}}$ \\
$\mathrm{s} \infty$ & $0.033^{\mathrm{c}}$ & $0.036^{\mathrm{b}}$ & $0.047^{\mathrm{b}}$ & $0.033^{\mathrm{c}}$ & $0.032^{\mathrm{c}}$ & $0.048^{\mathrm{c}}$ & $0.032^{\mathrm{d}}$ & $0.035^{\mathrm{b}}$ & $0.047^{\mathrm{c}}$ \\
\hline
\end{tabular}

Same letters between lines indicate lack of statistical difference; Scott-Knott test for multiple comparisons of the means; significance level of 0.05 . 
may affect positively the resistance of hexagon, while the connection key of S implants is larger near external hexagon, touching this portion of S implants (Fig. 2). This fact may cause lower resistance on EH of S group. Although external hexagon implants using a mounting device present higher resistance to insertion torque compared with other systems with smaller hexagon connections or internal connections (20), it is important to analyze the geometry of internal connection according to the results of the present study.

These findings suggest that the IA, EA and ID of EH may be affected by different torque levels. These changes are directly related to the increase in torque and were greater in the $\mathrm{S}$ group compared with the $\mathrm{N}$ group. The importance of these comparative mechanical studies lies on the collection of information concerning the limitations of different $\mathrm{EH}$ connections, information of great clinical relevance. Since were evaluated the levels of deformation of EH following the application of torque in vitro, it is suggested that the levels of deformation in dynamic conditions or clinical settings be investigated in further studies.

\section{Resumo}

Falhas podem ocorrer em conexões de implantes dentários, em especial em hexágonos externos $(\mathrm{EH})$. Devido à ocorrência de deformação nesta porção dos implantes, este estudo objetivou avaliar os niveis de deformação de conexões EH submetidas ao torque interno. Dois tipos de implantes foram utilizados: grupo $\mathrm{N}$ e grupo $\mathrm{S}$. Foram aplicados torques de 0,32 , 45,60 e $80 \mathrm{Ncm}$ nos implantes do grupo $\mathrm{N}$ e torques de $0,30,40,60$ $\mathrm{Ncm}$ e infinito nos implantes do grupo $\mathrm{S}$. Medidas referentes à distância interna (ID), área interna (AI) e área externa (AE) foram obtidas por meio de fotos digitais analisadas em software. A análise estatística foi feita pelo teste de Scott-Knott. Os resultados demonstraram que quanto maior o torque aplicado, maior a alteração de todas as dimensões avaliadas em ambos os grupos. No grupo $\mathrm{S}$, torques iguais ou superiores a $40 \mathrm{Ncm}$ e 30 $\mathrm{Ncm}$ causaram maior deformação na AE e Al respectivamente, enquanto no grupo $\mathrm{N}$, torques iguais ou superiores a $60 \mathrm{Ncm}$ e $32 \mathrm{Ncm}$ causaram
A

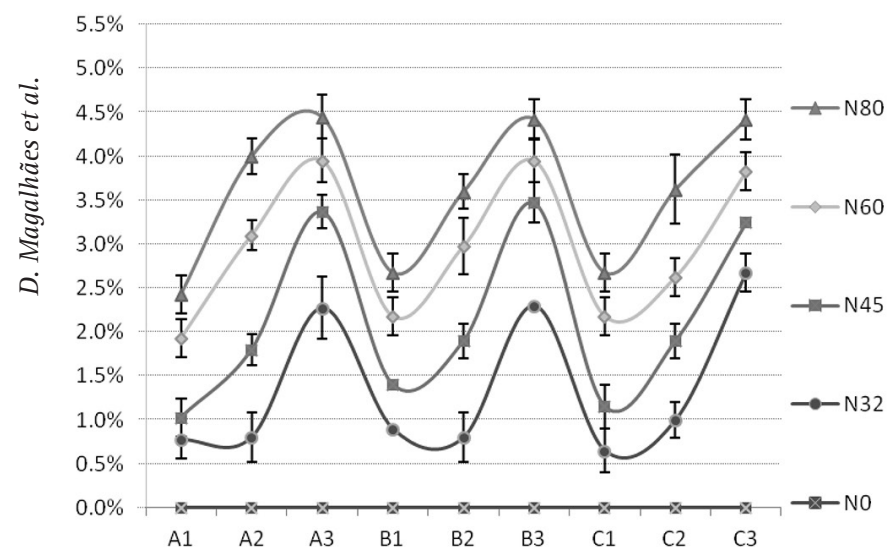

B

\section{Deformation}

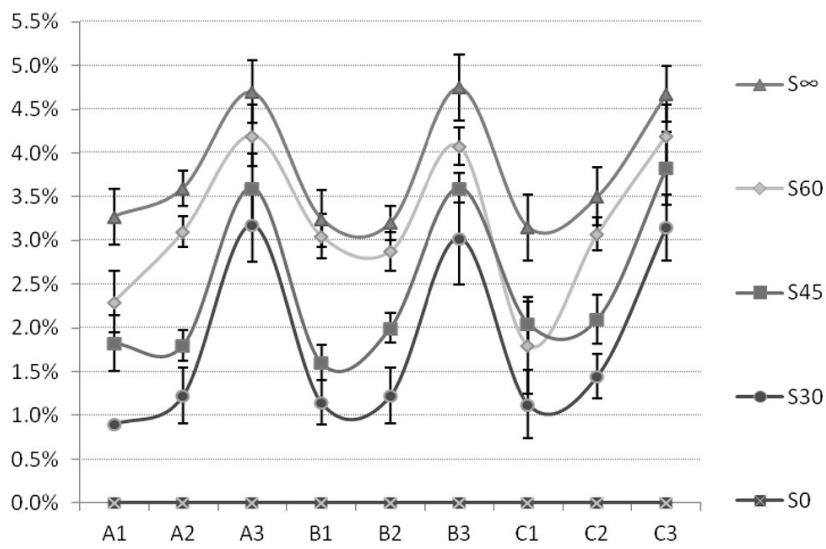

Figure 5. A: Mean and standard deviations of deformations (\%) in response to the different levels of torque applied at points A1, A2, A3, B1, B2, B3, $\mathrm{C} 1, \mathrm{C} 2$ and $\mathrm{C} 3$ in the $\mathrm{N}$ group. B: Mean and standard deviations of deformations (\%) in response to the different levels of torque applied at points $\mathrm{A} 1, \mathrm{~A} 2, \mathrm{~A} 3, \mathrm{~B} 1, \mathrm{~B} 2, \mathrm{~B} 3, \mathrm{C} 1, \mathrm{C} 2$ and $\mathrm{C} 3$ in the $\mathrm{S}$ group.

A

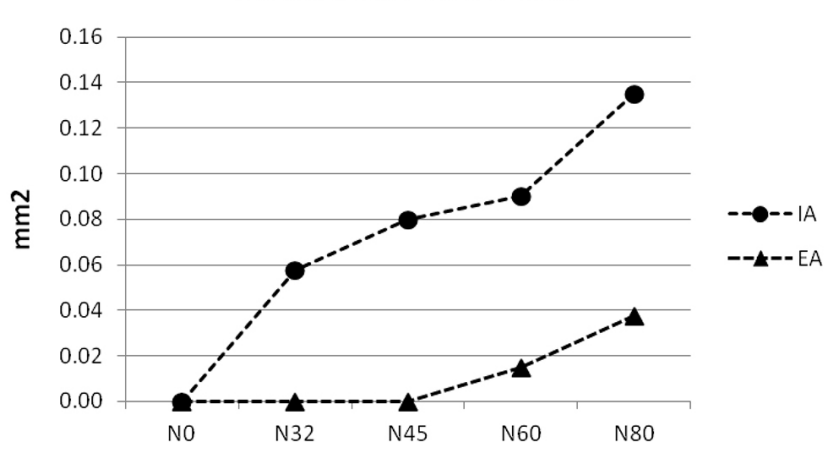

B

Area enhancement

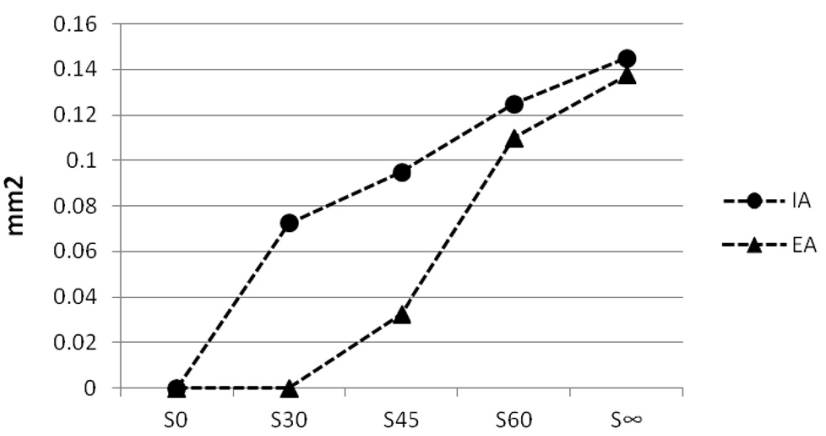

Figure 6. A: Internal and external areas ( $\mathrm{mm} 2)$ in response to the different levels of torque applied in the $\mathrm{N}$ group. B: Internal and external areas ( $\mathrm{mm} 2$ ) in response to the different levels of torque applied in the $\mathrm{S}$ group. 
maior deformação na AE e Al respectivamente. Os niveis de deformação foram maiores no grupo $\mathrm{S}$ em comparação ao grupo N. Nossos resultados indicam que a $\mathrm{Al}$, a $\mathrm{AE}$ e a $\mathrm{DI}$ do $\mathrm{EH}$ podem ser influenciadas pelos diferentes torques internos.

\section{Acknowledgements}

The authors thanks to CNPq and FAPEMIG for the financial support, and Neodent ${ }^{\oplus}$ and $\mathrm{SIN}^{\circledR}$ for the research incentive.

\section{References}

1. Abuhussein H, Pagni G, Rebaudi A, Wang HL. The effect of thread pattern upon implant osseointegration. Clin Oral Implants Res 2010;21:129-136.

2. Almeida EO, Freitas Júnior AC, Bonfante EA, Rocha EP, Silva NR, Coelho PG. Effect of microthread presence and restoration design (screw versus cemented) in dental implant reliability and failure modes. Clin Oral Implants Res 2013;24:191-196.

3. Freitas Júnior AC, Bonfante EA, Silva NR, Marotta L, Coelho PG. Effect of implant-abutment connection design on reliability of crowns: regular vs. horizontal mismatched platform. Clin Oral Implants Res 2012;23:1123-1126.

4. Wicks RA, deRijk WG, Windeler AS. An evaluation of fit in osseointegrated implant components using torque/turn analysis. J Prosthodont 1994;3:206-212.

5. Branemark $\mathrm{PI}$, Hansson $\mathrm{BO}$, Adell $\mathrm{R}$, Breine $\mathrm{U}$, Lindströn J, Hallén $\mathrm{O}$, et al.. Osseointegrated implants in the treatment of the edentulous jaw: experience from a 10-year period. Scand J. Plast Reconstr Surg 1977;16:1-132.

6. Trisi P, Perfetti G, Baldoni E, Berardi D, Colagiovanni M, Scogna G. Implant micromotion is related to peak insertion torque and bone density. Clin Oral Implants Res 2009;20:467-471.

7. Barbosa GAS, Simamoto Júnior PC, Fernandes Neto AJ, Mattos MGC, Neves FD. Prosthetic laboratory influence on the vertical misfit at the implant/UCLA abutment interface. Braz Dent J 2007;18:139-143.

8. lijima M, Muguruma T, Brantley WA, Okayama M, Yuasa T, Mizoguchid I. Torsional properties and microstructures of miniscrew implants. Am J Orthod Dentofacial Orthop 2008;134:333.e1-6; discussion 333-334.
9. Binon PP, McHugh MJ. The effect of eliminating implant/abutment rotational misfit on screw joint stability. Int J Prosthodont 1996;9:511519.

10. Vigolo P, Majzoub Z, Cordioli G. Measurement of the dimensions and abutment rotational freedom of gold-machined 3i UCLA-type abutments in the as-received condition, after casting with a noble metal alloy and porcelain firing. J Prosthet Dent 2000;84:548-553.

11. Vigolo P, Fonzi F, Majzoub Z, Cordioli G. An in vitro evaluation of ZiReal abutments with hexagonal connection: in original state and following abutment preparation. Int J Oral Maxillofac Implants 2005;20:108-14.

12. Merz BR, Hunenbart $S$, Belser UC. Mechanics of the implant- abutment connection: an 8-degree taper compared to a butt joint connection. Int J Oral Maxillofac Implants 2000;15:519-526.

13. Alsaadi G, Quirynen $M$, Michiels $K$, Jacobs $R$, van Steenberghe D. A biomechanical assessment of the relation between the oral implant stability at insertion and subjective bone quality assessment. J Clin Periodontol 2007;34:359-366.

14. Sakoh J, Wahlmann U, Stender E, Nat R, Al-Nawas B, Wagner W. Primary stability of a conical implant and a hybrid, cylindric screw-type implant in vitro. Int J Oral Maxillofac Implants. 2006;21:560-566.

15. Scott AJ, Knott MA. A cluster analysis method for grouping means in the analysis of variance. Biometrics. Raleigh, v.30, n.3, 1974. p 507-512.

16. Davi $L R$, Golin $A L$, Bernardes $S R$, Araújo $C A$, Neves FD. In vitro integrity of implant external hexagon after application of surgical placement torque simulating implant locking. Braz Oral Res 2008;22:125-131.

17. Lang $L A$, Wang RF, May KB. The influence of abutment screw tightening on the screw joint configuration. J Prosthet Dent 2002;87:74-79.

18. Theoharidou A, Petridis HP, Tzannas K, Garefis P. Abutment screw loosening in single-implant restorations: a systematic review. Int J Oral Maxillofac Implants 2008;23:681-690.

19. Malaguti G, Denti L, Bassoli E, Franchi I, Bortolini S. Dimensional tolerances and assembly accuracy of dental implants and machined versus cast-on abutments. Clin Implant Dent Relat Res 2011;13:134140.

20. Nary Filho H, Calvo Guirado JL, Matsumoto MA, Bresaola MD, Aur R. Biomechanical evaluation of resistance to insertion torque of different implant systems and insertion driver types. Implant Dent 2015 24:211216. 